\title{
Yield Spreads and Interest Rate Movements: A Bird's Eye View
}

\section{Citation}

Campbell, John Y., and Robert J. Shiller. 1991. Yield spreads and interest rate movements: a bird's eye view, in The Econometrics of Financial Markets, special issue, Review of Economic Studies 58, no. 3: 495-514.

\section{Published Version}

http://dx.doi.org/10.2307/2298008

\section{Permanent link}

http://nrs.harvard.edu/urn-3:HUL.InstRepos:3221490

\section{Terms of Use}

This article was downloaded from Harvard University's DASH repository, and is made available under the terms and conditions applicable to Other Posted Material, as set forth at http:// nrs.harvard.edu/urn-3:HUL.InstRepos:dash.current.terms-of-use\#LAA

\section{Share Your Story}

The Harvard community has made this article openly available.

Please share how this access benefits you. Submit a story.

Accessibility 
NBER WORKING PAPER SERIES

YIELD SPREADS AND INTEREST RATE MOVEMENTS: A BIRD'S EYE VIEW

John Y. Campbell

Robert J. Shiller

Working Paper No. 3153

NATIONAL BUREAU OF ECONOMIC RESEARCH

1050 Massachusetts Avenue

Cambridge, MA 02138

October 1989

This paper was prepared for presentation at the LSE Conference on the Econometrics of Financial Markets, June 1989. We are grateful to Ludger Hentschel for able and dedicated research assistance, to the National Science Foundation for financial support, and to the LSE Financial Markets Group for its hospitality. This paper is part of NBER's research program in Financial Markets and Monetary Economics. Any opinions expressed are those of the authors not those of the National Bureau of Economic Research. 
NBER Working Paper \#3153

October 19B9

YIELD SPREADS AND INTEREST RATE MOVEMENTS: A BIRD'S EYE VIEW

\section{ABSTRACT}

The expectations theory of the term structure implies that the spread between a longer-term interest rate and a shorter-term incerest rate forecasts two subsequent interest rate changes: the change in yield of the longer-term bond over the 1 ife of the shorter-term bond, and a weighted average of the changes in shorter-term rates over the life of the longer-term bond. For postwar U.S. data from McCulloch [1987] and fust about any combination of maturities between one month and ten years we find that the former relation is not borne out by the data, the latter roughly is. When the yield spread is high the yield on the longer-term bond tends to fall, contrary to the expectations theory; at the same time, the shorter-term interest rate tends to rise, just as the expectations theory requires. We discuss several possible interpretations of these findings. We argue that they are consistent with a model in which the spread is a multiple of the value implied by the expectations theory. This model could be generated by time-varying risk premia which are correlated with expected increases in short-term interest rates, or by a failure of rational expectations in our sample period.

John Y. Campbe11 Financial Markets Group London School of Economics Houghton Street London WC2A $2 \mathrm{AE}$ United Kingdom (01)405-7686, ext. 3106
Robert J. Shiller Cowles Foundation Yale University Box 2125 Yale Station New Haven, CT 06520 (203) $432-3708$ 


\section{Introduction}

Does the slope of the term structure - the yleld spread between longer-term and shorter-term incerest rates - predict future changes in Interest rates? And if so, is the predictive power of the yleld spread in accordance with the expectations theory of the term structure?

These questions are important, both for forecssting interest rates and for interpreting shifts in the yield curve. If the expectations theory is an adequate description of the term structure, then expectations of future interest rates are the dominant force determining current longterm interest rates. On the other hand, if the expectations theory is very far from accurate, then predictable changes in excess returns must be the main influence moving the term structure. It makes sense to thoroughly explore the validity of the simple expectations theory before undertaking a detalled study of the sources of predictable time variation in excess returns.

The literature on the term structure contains a bewildering variety of answers to these questions. Almost all studies statistically reject the expectations theory of the term structure; but some studies suggest that the yield spread does predict interest rate movements in roughly the way one would expect if the expectations theory is true, while other studies

1 We refer to "the" expectations theory of the term structure. One problem that has hampered empirical work is that in fact there are many different versions of the expectations theory, as emphasized by Cox, Ingersoll, and Ross [1981] and others. We have however argued elsewhere that these different expectations theories are in important respects very similar, and are all closely approximated by a single linear expectations theory (Shiller [1979], Shiller, Campbe1l, and Schoenholtz [1983], Campbel1 (1986]). Note also that we are including the hypothesis of rational expectations in our definition of the expectations theory. This contrasts with the usage of some authors (e,g. Froot [1989]). 
reach the opposite conclusion. Different studies use different econometric methods, test different implications of the expectations theory, and look at different interest rate maturities.

In this paper we show that certain statements can be made quite generally. For any palr of macurities $n$ and $m$, where $n$ exceeds $m$ (so $n$ is the "long-term" rate and $m$ is the "short-term" rate), the following is true: When the spread between the $n$-period race and the m-period rate is relatively high, the yield on the $n$-period bond tends to fall over the life of the m-perlod bond. This runs counter to the expectations theory. At the same time, m-perlod rates tend to rise over the life of the $n$ period bond, in accordance wh the expectations theory. In plain English, when the spread is high the long rate cends to fall and the short rate tends to rise.

The data set used here consists of continuously compounded yields on riskless pure discount bonds. These yields were calculated by McCulloch [1987] from raw data on U.S. Treasury bill, note and bond prices, measured over the period 1952:1-1987:2 at the end of each month. ${ }^{2}$ We will present results for all possible pairs of maturities in the range 1 , $2,3,4,6$, and 9 months and $1,2,3,4,5$, and 10 years. Thus, the results in this paper are a group of two-dimensional tables of evaluations of the linear expectations theory. While the rain findings hold over all possible sets of maturities, there are some interesting differences between the behavior of the short end of the term structure

2 McCulloch's data actually begin in 1946:12, but we drop the data from the period before the Treasury Accord of 1951 . 
(maturities less than one year) and the long end of the term structure (maturities greater than one year). We discuss these further below.

The organizacion of the paper is as follows. In section 2 we derive the implications of the expectations theory of the term structure for the relation between yield spreads and subsequent interest rate movements. We discuss several ways in which these implications can be tested. including regresston methods and a modiflcation of the vector autoregressive approach of Campbell and Shiller [1987]. In section 3 we apply these methods to the McCulloch tern structure data. We also use a Monte Carlo study to check the fintte-sample properties of our procedures. In section 4 we try to interpret our results further. We argue that one simple alternative, In which the yield spread equals its value under the expectations theory plus orthogonal noise. Is not consistent with the data. We suggest another alternative, which makes the yleld spread a constant multiple of its value under the expectations theory. This model could be generated by time-varying risk premia which are correlated with expected increases in short-term interest races, or by a fallure of rational expectations in our sample period. 


\section{The Expectations Theory of the Term Structure}

The expectations theory of the cerw structure of interest rates is a relationship between the $n$-period interest rate $R_{t}^{(n)}$ and m-period interest rate $R_{t}^{(m)}$, where $n / m$ is an inceger. In the case of pure discount bonds, as with our data here, this is:

(1) $R_{t}^{(n)}-(1 / k) \sum_{i=0}^{k-1} E_{t} R_{t+m i}^{(m)}+c, k-n / m$.

Equation (I) states that the n-period rate is a constant, plus a simple average of the current and expected future m-period rates up to $n-m=$ $(k-1)$ meriods in the future. Note that the sum of the coefficients of the m-period interest rates is one. The parameter c reflects a cerm premium, that is a predictable excess return on the $n$-period bond over the m-period bond. The cerm premium may vary with m and $n$ but is assumed to be constant through time.

Equation (1) can be obtained directly if one assumes that expected continuously compounded yields to maturity on all discount bonds are equal, up to a constant: this is the approach caken by Fama [1984]. Equation (1) can also be derived as a linear approximation to any of several different nonlinear expectations theories of the cerm structure. The approximation is quite adequate for most purposes (Shiller, Campbell, and Schoenholcz [1983], Campbell (1986]). For example, if one assumes that the expected cotal return over in periods on buying an n-period bond and selling it m periods later equals the return on holding an m-period bond to maturity plus a constant, then one finds that the expectation of 
a nonlinear expression in $R_{t}^{(n)}$ and $R_{t+m}^{(n-m)}$ equals $R_{t}^{(m)}$ plus a constant. Linearizing this expression around $R_{t}^{(n)}-R_{t+m}^{(n-m)}-0$, one gets a rational expectations model that if solved forward yields (1).

It should be noted that (1) is a time-consistent model. If the model holds for $\mathrm{m}-1$ and $a l l \mathrm{n}$, then $i t$ holds for $\mathrm{all}$ m $\geq 1$ and $\mathrm{all} \mathrm{n}$. This is an important property of the model; many time series models (as for example most ARIMA models) are not time consistent: an AR(2) model with monthly data is not consistent with an AR(2) model with quarterly data. There is no such problem here.

\section{The spread as a forecast of changes in interest rates}

Our purpose is to state in the simplest possible terms what elements of truth can be found in the expectations theory of the term structure. We therefore concentrate our attention on the behavior through time of a simple measure of the shape of the term structure: the spread between the $n$-period rate and the m-period rate, $s_{t}^{(n, m)}-R_{t}^{(n)}-R_{t}^{(m)}$. The spread is of course proportional to the slope of the term structure between $m$ and n.

The expectations theory of the term structure implies that the spread is a constant risk premium, plus an opt1mal forecast of changes in future Interest rates. We can test the model by regressing the appropriate changes onto the spread and testing whether the coefficient equals one. And we can, apart from testing the model, evaluste its usefulness by checking to what extent the spread resembles an optimal forecast of the changes in interest rates.

There are several ways to write the spread as a forecast of future changes in interest rates. First, the spread predicts the m-period 
change in yield on the longer-term bond. This bond has $n$ periods to maturity at time $t$, so it has $n-m$ periods to maturity at time $t+m$. According to the expectations theory,

$$
(m /(n-m)) S_{t}^{(n, m)}-E_{t} R_{t+m}^{(n-m)} \cdot R_{t}^{(n)} .
$$

where for simplicity we are suppressing constant terms. The intuition behind equation (2) is that if the yield on the $n$-period bond is expected to rise over the next $m$ periods, this will give a capital loss to holders of the bond. To equate expected returns over $m$ periods, the $n$-period bond has to have a higher current yield than the m-period instrument. One may test (2) by regressing $R_{t+m}^{(n-m)}-R_{t}^{(n)}$ onto a constant and its predicted value $s_{t}^{(n, m)}$ defined as: $s_{t}^{(n, m)}-(m /(n-m)) s_{t}^{(n, m)}$. The slope coefficient should be one.

Second, by subtracting $R_{t}^{(m)}$ from both sides of equation ( 1 ) and rearranging terms, one can show that the spread forecasts a weighted average $s_{t}^{(n, m) *}$ of changes in shorter-term (m-period) interest rates over n periods:

$$
\begin{aligned}
& s_{t}^{(n, m)}=E_{t} s_{t}^{(n, m) *}, \\
& \left.s_{t}^{(n, m) \star}-(1 / k) \sum_{i=1}^{k-1} \sum_{j=1}^{i} \Delta^{m} R_{t+j n^{\prime}}^{(m)}\right)=\sum_{i=1}^{k-1}(1-i / k) \Delta^{m} R_{t+1 m}^{(m)} .
\end{aligned}
$$

The notation $\Delta^{m}$ indicates that a change is measured over $\mathrm{a}$ periods, so for example $\Delta^{m} R_{t+m}^{(m)}-R_{t+m}^{(m)}-R_{t}^{(m)}$. 
The variable $s_{t}^{(n, m) *}$ may be called the "perfect foresight spread", since it is the spread that would obtain given the model if there were perfect foresight about future interest rates. With perfect foresight, if m-period rates are going to rise over the life of the n-period bond, then the $n$-period yield needs to be higher than the current m-period yield to equate the returns on the n-period bond, held to maturity, and a sequence of m-period bonds. Below we shall regress the perfect foresight spread onto a constant and the actual spread to evaluate the model. The slope coefficient should be one.

Equations (2) and (3) are complete characterizations of the expectations theory of the cerm structure; if (2) holds for all m and $n$. then (3) holds for all m and $n$, and vice versa. However it is important to note that for any particular values of $m$ and $n$, the validity of (2) does not generally imply the validity of (3) or vice versa.

An exception to this statement occurs when $n-2 m$, a case that is often studied in empirical work. ${ }^{3}$ In this case equations (2) and (3) take particularly simple forms because $R_{t+m}^{(n-m)}$ equals $R_{t+m}^{(m)}$ in equation (2), while the weighted sum on the right hand side of (3) has only one element. Equation (2) becomes

(4) $\quad s_{t}^{(n, m)}-E_{t} R_{t+m}^{(m)}-R_{t}^{(n)}$. and (3) becomes

3 See for example Shiller, Campbe11, and Schoenholtz [1983], who look at 3 and 6 month Treasury bills. 
(5) $\quad s_{t}^{(n, m)}=(1 / 2) E_{t} \Delta^{m} R_{t+m}^{(m)}=(1 / 2) E_{t}\left[R_{t+m}^{(m)}-R_{t}^{(m)}\right]$.

Equation (4) says that the spread equals the difference between the optimal forecast of the m-period rate m periods from now and the $n$ period rate coday, while equation (5) says that the spread equals onehalf the optimal forecast of the change in the m-period rate over the next m periods. If (4) holds for a particular and an, then (5) must also hold, and vice versa. (To see this, just subtract $R_{t}^{(m)}$ from both sides of (4) and rearrange.)

Since (4) and (5) are special cases of (2) and (3), they can be cested using the same regression approach. If the regression coefficient for the test of (4) is written $b$, the regression coefficient for the test of (5) will be $(1+b) / 2$.

\section{The theoretical spread}

Regression tests of the expectations theory have the great merit of simplicity. 8ut they also have some serious disadvantages. First, the regression of the perfect foresight spread onto the actual spread involves n-period overlapping errors. One only has an entirely independent observation of the forecast power of the term structure every n periods. While econometric methods are available to correct regression standard errors for overlap, they do not work well when the degree of overlap is large relative to the sample size. (See for example Stock and Richardson (1989].) Since $n$ can be as large as 10 years, and we have only 35 years of daca, this is a worrisone problem.

Secondly, regression tests do not tell us how similax are the movements of the actual spread to the movements implied by the 
expectations theory. We would like to evaluate the ability of the expectations theory to explain the shape of the term structure, and regression tests are not well sulted for this purpose.

In earlier work (Campbell and Shiller [1987]), we proposed a vector autoregressive (VAR) approach for evaluating present value models. That paper dealt with the case in which $n$ is infinite, but the approach can easily be modified to handle a finite value of $n$. The VAR approach avoids the need to estimate regressions with overlapping errors. The VAR includes the 1 -period change in the m-period interest rate, and the actual yield spread. From the estimated VAR coefficients, one can compute the optimal forecast of m-period interest rate changes over any horizon; the long-run behavior of interest rates is inferred from their short-run behavior in the sample period, rather than being estimated directly. The appropriate weighted average of forecast interest rate changes (the "theoretical spread") can be calculated, and compared with the actual spread. If the expectations theory is true, the two variables should be the same.

The details of the VAR approach are given in Campbell and Shiller [1987]; here we merely sumnarize the method and show how we can apply it to the expectations theory with a finite horizon $n$. We assume first of all that $\Delta R_{t}^{(m)}$ is a stationary stochastic process, from which it follows that $x_{t}=\left[\Delta R_{t}^{(m)}, s_{t}^{(n, m)}\right]$ is a stationary vector stochastic process. We shall suppose that it can be represented as a $p^{\prime}$ th order VAR. This system can be rewritten as a first-order VAR in the companion form $z_{t}$ $A z_{t-1}+u_{t}$, where $z_{t}$ has $2 p$ elements, first $\Delta R_{t}^{(m)}$ and $p-1$ lags and then 
$s_{t}^{(n, m)}$ and p-1 lags. Multi-period interest rate forecasts are easily computed from the companion form, since $E_{t} z_{t+k}=A^{k} z_{t}$.

We next define vectors $g$ and $h$ such that $g^{\prime} z_{t}=s_{t}^{(n, m)}$ and $h^{\prime} z_{t}=$ $\Delta R_{t}^{(m)}$. Then using (3) we can compute the VAR forecast of the perfect foresight spread; we write this forecast $s_{t}^{\prime}(n, m)$. Tedious algebra shows that $s_{t}^{(n, m)}$ can be expressed as 4

$$
s_{t}^{(n, m)}=h^{\prime} A\left[I-(m / n)\left(I-A^{n}\right)\left(I-A^{m}\right)^{-1}\right](I-A)^{-1} z_{t}
$$

We call $s_{t}^{(n, m)}$ the "theoretical spread", since it is the spread which would obtain if the expectations theory were true. The expectations theory implies

(7) $\quad s_{t}^{(n, m)}=g^{\prime} z_{t}=s_{t}^{(n, m)}$.

Note that (7) should hold even if economic agents are using more information to forecast than is contained in the vector $z_{t}$ " since the actual spread is contained in the vector $z_{t}$.

The equality of the actual spread and the theoretical spread puts a set of nonlineer restrictions on the coefficients of the estimated VAR. Thege can be tested formally using a Wald test (Campbell and shiller [1987]). We do not pursue this approach here, since the regression methods discussed above are simpler if one's purpose is merely to test the model. Instead, we use the VAR to compare the historical behavior of

4 Note that this expression reduces to the much simpler formula in Campbel1 and Shiller [1987] when $n$ is infinite. 
$S_{t}^{(n, m)}$ and $S_{t}^{(n, m)}$. We compute the correlation of $s_{t}^{(n, m)}$ and $s_{t}(n, m)$, and the ratio of their standard deviations. If $s_{t}^{(n, m)}$ equals $s_{t}^{(n, m)}$, of course, the correlation and the standard deviation ratio should both equal one.

\section{Some previous results}

We found in our earlier work (Shiller [1979], Shiller, Campbell and Schoenholtz (1983)) that for very large $n$ and $\operatorname{small} m$ when $R_{t+m}^{(n-m)} \cdot R_{t}^{(n)}$ is regressed on $s_{t}^{(n, m)}$ then the coefficient of $s_{t}^{(n, m)}$ tends often to be significantly different from one. In fact, the point estimate is negative. We concluded that the theory was very far off track, that the expectations theory of the term structure is just wrong.

In later work (Campbell and Shiller [1987]), we used a different metric to evaluate the expectations theory for large $n$ and $s m a 11$, and we found that the expectations theory seemed to work fairly well. We computed the correlation between $S_{t}^{(n, m)}$ and $s_{t}^{(n, m)}$ and found it to be quite high. This suggests that the actual spread behaves much as it should according to the expectations model. ${ }^{6}$ The correlation between $S_{t}^{(n, m)}$ and $S_{t}^{(n, m)}$ can be high and still we may get a wrong sign in a regression test of equation (2); for example, this can happen if $s_{t}^{(n, m)}$ equals $S_{t}^{(n, m)}$ plus a small serially uncorrelated noise term.

Other recent work has also emphasized the ability of the yield spread to forecast short rate changes over long horizons. Fama and Bliss [1987] set $m=1$ year and $n-2,3$, and 4 years. They work with "forward

S See also Mankiw and Summers [1984] and Froot [1989].

6 Shiller [1989a] uses plots of the actual spread and the perfect foresight spread to make the same point. 
premia*, which are linear combinations of two different yleld spreads. According to the expectations theory, forward premia should forecast unweighted averages of changes in short rates, as opposed to the weighted averages forecast by yield spreads. Fama and B1lss regress the appropriate short rate changes onto forward premia, and find that the forecasting power of the term structure improves as the horizon $n$ increases. They attribute this to a slowly mean-reverting interest rate process which is more easily forecast over long time perlods than over short intervals.

A largely unrelated literature has looked at the short end of the term structure, with $n$ up to 12 months. Shiller, Campbell, and Schoenholtz [1983] found that the yield spread between 3 and 6 month Treasury bill rates helps to forecast the change in the 3 month bill rate, but not as strongly as the expectations theory requires. Fama [1984] found some evidence that the slope of the term structure predicts interest rate changes over a few months, but the predictive power seemed to decay rapidly with the horizon.

7 Mishkin [1988a] has updated the results in Fama [1984], Fama [1988] and Mishkin [1988b,c] extend the analysis to look at the forecast power of the yleld curve, at both short and long horizons, for future inflation rates. See Shiller [1989b] for a survey of other research on the tern structure. 


\section{Data and Empirical Results}

The McCulloch monthly term structure data [1987] give pure discount (zero coupon) bond yields for U. S. Government securitles over the period 1946:12-1987:2. We use the sample 1952:1-1987:2, to allow for lags and to exclude data from before the Treasury Accord of 1951. The data include maturities of $0,1,2,3,4,5,6$, and 9 months, and 1, 2, 3, 4 , 5, and 10 years. Longer maturitles are available only for part of the sample. These data are continuously compounded yields to maturity.

of course, pure discount government bonds of long maturity do not exist. But existing government bonds may be regarded as portfolios of pure discount bonds, bonds maturing on all coupon dates and the maturity date. One may suppose that they are priced, except for some tax considerations, as the sum of the values of the constituent bonds in the portfolio. One can therefore infer the prices (and thus the yields) of the constituent bonds. There are problems in making this inference: there may be more than one way to infer the yield of a certain discount bond (giving possibly different answers in practice) and no way to infer the yield of other discount bonds (since coupon and maturity dates may not be evenly spaced through time). Thus, McCulloch [1987] inferred the discount yields by an interpolation method using cubic splines.

McCulloch's data are very clean in the sense that they are unaffected by differing coupons, coupon dates, or differing compounding conventions across maturities. They are 1deally suited to the kind of analysis we

8 Fama and Bliss [1987] infer yields on pure discount bonds using the assumption that instantaneous forward rates are step functions of maturity. This is an alternative to McCulloch's procedure. Our results below are similar to those of Fama and Bliss for the maturities they consider. 
wish to do here over a broad range of maturitles. The data are not interval averaged, but are observed at the end of each month.

Forecasting the chanre in the longer-term yield

Table la confirms that the slope of the term structure between almost any two maturities ( $m$ and $n$, where $n>m$ ) gives the wrong direction of forecast for the change in yield of the longer term (n-period) bond over the life of the shorter term (m-period) bond. 9 Asymptotic standard errors, which have been corrected for heteroskedasticity and equation error overlap in the manner of Hansen and Hodrick [1980] and white [1984], show that almost all the coefficients are significantly different from one at conventional significance levels. Thus, earlier conclusions in Shiller [1979] and Shiller, Campbell and Schoenholtz [1983] for some maturities are found to extend to just about all maturity pairs m and $n$. By this metric, the expectations theory of the term structure is a resounding fallure.

The general tendency for wrong signs to appear throughout the table is robust to the sample period. In Table lb we report results for the case m - 1 over a variety of subsamples, including the 1952-78 period (the longest possible subsample which avoids the 1979 monetary policy regime shift) and the shorter periods 1952-59, 1960-69, 1970-78 and 1979-87. We find a predominance of wrong signs in every period except 1952-59.

As a check on the McCulloch data, these results can be compared with earlier results using different monthly data on U.S. Treasury

9 The lower left-hand part of the table, where $n$ is Iarge and $a$ is small, uses the approximation that $R_{t+m}^{(n-m)}=R_{t+m}^{(n)}$. In the rest of the table we give results only where we observe $R_{t+m}^{(n-m)}$ directly. 
obligations. Shiller, Campbell, and Schoenholtz [1983] found that when the three monch change in the chree month race is regressed on the predicted change implicit in the spread between six-month and three-month rates, with daca January 1959 to June 1979, the slope coefficient was 0.285 . Here, the slope coefficient in Table la for $\mathrm{m}^{-3}$ and $n-6$ is b - -1.279 . The implied slope coefficient for the regression run by Shiller, Campbell, and Schoenholtz is $(1+b) / 2-0.140$. If we use the January 1959 to June 1979 sample our estimated b is -0.302 so that $(1+b) / 2-0.348$, which compares reasonably well with the earlier result. Fama [1984] found that when the actual change over one monch in the onemonth rate is regressed using data $1959-82$ on the predicted change the slope coefficient is 0.46 . Our $(1+b) / 2$ from Table $1 a$ is 0.51 , and if $b$ is reestimated using their sample period $b=-0.302$ and $(1+b) / 2-0.54$. Fama and Bliss [1987] found that when the actual change in the one year rate over one year is regressed 1964-84 on the predicted change the slope coefficient is 0.09 . Using our Table $1 a,(1+b) / 2--0.14$, using their sample period $b--0.882$ and $(1+b) / 2-0.06$. These comparisons show that the McCulloch data give similar results to results with other daca sets.

\section{Forecasting chanres in short races}

Table 2 shows the results of regressing $s_{t}^{(n, m) *}$ on $s_{t}^{(n, m)}$ for combinations of $n$ and $m$ that are represented in the McCulloch data, for which $n$ is an integer multiple of $\mathrm{m}$. The regression coefficients should be one if the expectations hypothesis is valid. In fact, the coefficients are almost always positive but also deviate substantially frow one when the maturity $n$ of the longer-term bond is below 3 or 4 years. At this short end of the cerm structure, asymptotic standard 
errors inply rejection of the expectations theory at conventional significance levels. At the long end of the term structure, the regression coefficients are very close to one and the expectations theory is not rejected.

We thus see an apparent paradox: the slope of the term structure almost always gives a forecast in the wrong direction for the short-term change in the yield on the longer bond, but gives a forecast in the right direction for long-term changes in short rates. We next use our VAR procedures in order to judge how the spread moves through time in relation to an unrestricted forecast of changes in short rates.

Table $3 a$ reports correlations between the actual spread $s_{t}^{(n, m)}$ and the estimated theoretical spread $s_{t}^{(n, m)}$. For each estimated correlation we first ran a fourth order vector autoregression for the vector $\left[\Delta R_{t}^{(m)}\right.$, $s_{t}^{(n, m)}$ ]' using monthly data from January 1952 to February 1987 and used the result to form the A matrix for the companion fort. This estimate of A was then substituted into equation (7) to arrive at $s_{t}^{(n, m)}$, and the correlation with $s_{t}^{(n, m)}$ computed. An asymptotic standard error was calculated in the way described in Campbell and Shiller [1987]. The correlation is almost always positive and often very high. This result also holds up in subsamples, as shown in Table $3 b$.

Table 4a shows the standard deviation of $s_{t}^{(n, m)}$ divided by that of $s_{t}^{(n, m)}$. We find that the coefficient is typically around one-half, regardless of $m$ and $n$. Thus, the spread is too variable to accord with the simple expectations model. Similar results hold in all subsamples (Table 4b), except for large $n$ in the 1952-59 period. 
These results can be compared to results in Table 2 in the following way. The product of an element in Table $3 a$ (the correlation of $s_{t}(n, m)$ and $S_{t}^{(n, m)}$ ) and the corresponding element in Table $4 \mathrm{a}$ (the standard deviation of $s_{t}^{(n, m)}$ divided by the standard deviation of $s_{t}^{(n, m)}$ ) is the regression coefficient when $s_{t}^{(n, m)}$ is regressed on $s_{\varepsilon}^{(n, m)}$. This regression coefficient should be (except for sampling error) the same as that in Table 2. We find that they are about the same when $n$ is small, but diverge substantially when $n$ is large.

There are two possible explanations for this discrepancy. First, in order to regress $s_{t}^{(n, m) *}$ on $s_{t}^{(n, m)}$ we must truncate the sample enough to allow computation of $s_{t}^{(n, m) \star}$ which requires data $n$-Il periods into the future. (For this reason we do not try to apply the approach of Table 2 in subsamples.) To do the calculations in Tables 3 and 4 there is no such need to truncate the sample. Thus, the discrepancy in resules might just be due to different sample periods, and our estimates with shorter samples in Tables $3 \mathrm{~b}$ and $4 \mathrm{~b}$ show that this is a large part of the explanation.

A second possible reason for the discrepancy is that perhaps our vector autoregression truncated after four months is too short, and thus our estinate of $s_{t}^{(n, m)}$ is subject to error. In our previous work we have suggested that long lags may be useful in forecasting interest races (Campbell and Shiller (1984)). When we increase the lag length to eight months, we find that the estimated standard deviation ratio is roughly unchanged; the estimated correlation tends to fall, but is less precisely estimated. Overall, the increase in lag length does not reduce the discrepancy between the results in Table 2 and those in Tables 3 and 4 . 


\section{The effect of the forecast horizon}

Fama and Bliss [1987] have emphasized that the forecast power of the term structure for changes in short rates improves as the forecast horizon increases from 2 years to 5 years. Our study of the full range of maturities confirms this result, but shows that in fact below 1 year the forecast power deteriorates with the horizon. The forecast power reaches its minimum at 9 to 12 months, and then starts to 1mprove. This effect can be seen in the "U-shaped" pattern of coefficients as one moves down the first column of Table 2, Table 3a, or Table 4a. It is evident also in most of the subsamples in Tables $3 b$ and $4 \mathrm{~b}$.

The movements of longer-term ylelds, however, do not display this $U$ shaped pattern. In Tables $1 \mathrm{a}$ and $\mathrm{lb}$ the coefficients become increasingly negative as the horizon increases. The tendency of the long rate to fall when the spread is high is quite robust to the maturity of the longer. term instrument.

\section{Monte Carlo results}

Our VAR approach can also be used to generate artificial data for Monte Carlo simulations. It is known that there can be small-sample bias in standard errors of regressions with predetermined but not exogenous variables. (See Mankiw and Shapiro [1986] and Stambaugh [1986] for a discussion of this in the context of rational expectations models.) The problem is particularly serious when asymptotic corrections are used to handle equation error overlap which is large relative to the sample size (Stock and Richardson [1989]). Monce Carlo simulacions are an appealing way to avoid excessive reliance on asymptotic distribution theory. 
To generate data which match the moments of the actual data while obeying the restrictions of the expectations theory, we start by drawing normal random errors and feeding them through the VAR system estimated on the actual data. This gives us artificial time series for $\Delta R_{t}^{(m)}$ and $s_{t}^{(n, m)}$. We then replace $s_{t}^{(n, m)}$ with $s_{t}^{(n, m)}$, calcuiated using the true VAR coefficients (those estimated on the actual data and which generate the artificial data). This procedure can be used whenever $n / m$ is an integer. It gives us artificial data which obey the expectations theory in population, but not necessarily in each artificiai sample.

Tables ia, 2a, 3a, and 4 give two numbers for each entry which summarize the results of the Monte Carlo experiment. The first number is the fraction of 1000 runs which produced an estimated regression coefficient (or correlation, or standard deviation ratio) which was further away from one in the same direction (that is, usually, smalier) than the coefficient obtained in the data. This is a "one-sided" empirical significance level for the coefficient. The second number is the fraction of 1000 runs in which a t test of the expectations theory, computed using the asymptotic standard error on the coefficient, rejected the null more strongly than the $t$ test on the actual data. This is a "two-sided" empirical significance level for the expectations theory $t$ test. One can compare the empirical significance level with the significance level from the normal distribution to evaluate the quality of the asymptotic standard errors in the tables.

The Monte Carlo results show that there is some finite-sample bias in asymptotically valid regression tests of the expectations theory. The bias is particulariy noticeable when the order of equation error overlap 
is large (that is, for large m on the right hand side of Table 1 and for large $n$ at the bottom of Table 2). In these parts of the tables, the asymptotic standard errors greatly understate the true uncertainty about the regression coefflcients.

However this bias is not enough to overturn our conclusions about the expectations theory. In Table 1 the expectations theory is rejected very strongly at the short end, and comfortably at the long end. In Table 2 the theory is rejected at the short end but not the long end. The VAR procedures generally give weak evidence that the actual and theoretical spreads are imperfectly correlated, and stronger evidence that the actual spread has higher variability than the theoretical spread.

One interesting feature of the Monte Carlo results is that the two empirical signtficance levels are sometimes quite different from one another. For example, in Table 3a with $m-1$ and $n-24$, only 21 out of 1000 runs delivered a correlation between $s_{t}^{(n, m)}$ and $s_{t}^{(n, m)}$ that was lower than the one estimated in the data. But 749 out of 1000 runs delivered a correlation which was further from one when normalized by its asymptotic standard ertor. In this table, it seems that the artificial data sets tended to deliver higher correlations between $s_{t}^{(n, n)}$ and $s_{t}^{(n, m)}$ and saaller standard errors than are found in the actual data. We conjecture that this is due to heteroskedasticity in the actual data which is not captured by our Monte Carlo experiment. 


\section{Further Interpretation}

We have documented the fact that for any pair of maturities the yield spread falls to correctly predict subsequent movements in the yield on the longer term bond, yet it does forecast short rate movements in roughly the way implied by the expectations theory. The purpose of this section is to explore some possible explanations for this fact. The explanations we will consider are not finance-theoretic models of timevarying risk premia, but simply econometric descriptions of ways in which the expectations theory might fail.

One obvious alternative to the expectations theory is a model of the form

(8) $s_{t}^{(n, m)}=E_{t} s_{t}^{(n, m) *}+c+v_{t}$,

where $v_{t}$ is an er "or term which is orthogonal to $E_{t} S_{t}^{(n, m) \star}$. Equation (8) can generate a negative coefficient when $R_{t+m}^{(n-m)} \cdot R_{t}^{(n)}$ is regressed on $s_{t}^{(n, m)}$. since the error term $v_{t}$ appears positively in the independent variable and negatively in the dependent variable of this regression. Equation (8) also implies that the regression coeffictent when $S_{t}^{(n, m) \star}$ is regressed on $s_{t}^{(n, m)}$ is $1 /(1+V R)$, where $V R$ is the ratio of the variance of $v_{t}$ to the variance of $s_{t}^{(n, m) \star}$. The correlation coefficient between $E_{t} S_{t}^{(n, m) *}$ and $S_{t}^{(n, m)}$ and the ratio of the standard deviation of $E_{t} S_{t}^{(n, m) *}$ to the standard deviation of $s_{t}^{(n, m)}$ both equal the square root of $1 /(1+V R)$.

The VAR results in Tables 3 and 4 do not suggest that this model fits the data, since we found that the correlation coefficlent was very close 
to one while the ratio of standard deviations was roughly one half. It is also possible to test ( 8 ) more directly, if we impose extra orthogonality conditions on the error term $v_{t}$. For example, if we assume that $v_{t}$ is white noise, then any variables dated $t-1$ or earlier can be used as instruments in an instrumental variables regression of $R_{t+m}^{(n-m)}-R_{t}^{(n)}$ onto $s_{t}^{(n, m)}$. These lagged variables will be orthogonal to $v_{t}$. so the IV coefficient should be one as implied by the expectations theory. Alternatively, if wo assume that $v_{t}$ follows an MA(q) process, then any variables dated $t-q-1$ or earlier can be used as instruments.

In Table 5 we report the results of instrumental variables regressions of $R_{t+m}^{(n-m)}-R_{t}^{(n)}$ onto $s_{t}^{(n, m)}$. We set $m=1$ and use the full 1952-87 sample. For comparison, the first column reports the ols regression results from Table la. The next three colums give IV regression coefficients with standard errors, where the instruments are the spread lagged 1 month, 6 months, and 12 months respectively. The results are not encouraging for the model (8); the IV coefficients are always negative and of ten more so than the OLS coeffictents. Standard errors increase with the lag length of the instrument, but this does not provide any positive evidence in favor of (8). 10

An alternative orthogonality condition would be that $v_{t}$ is orthogonal to current and past short-term interest rates. If this is so, then the projection of the yield spread onto the history of short rates has the form implied by the expectations theory; the failure of the expectations theory is caused by the behavior of the error tarm in this projection.

10 These results are consistent with those reported in Campbell and Shiller [1987] using a VAR approach to test (8). 
We can test this idea by using current and lagged short rates as instruments in the IV regression of $R_{t+m}^{(n-m)} \cdot R_{t}^{(n)}$ onto $s_{t}^{(n, m)}$. In the last two columns of Table 5 we use the level of $R_{t}^{(1)}$, less a 12-month or 60-month backwards moving average of $R_{t}^{(1)}$, as an instrument. We write these variables as $x_{t, 12}$ and $x_{t, 60}$, respectively. $x_{t, 12}$ is a better instrument for shorter-term yield spreads, while $x_{t, 60}$ is a better instrument for longer-term yield spreads. But neither set of results is very encouraging for the model. At least over the period 1952-87, it appears that the component of the yield spread which is correlated with past short rates is at least partly responsible for the failure of the expectations theory. 11

These results suggest that equation (8) may be too restrictive to explain the data. A more pronising model may be

$$
\text { (9) } s_{t}^{(n, m)}-k E_{t} s_{t}^{(n, m) *}+c_{1}
$$

where the coefficient $k$ is greater than one. This model can also generate a negative coefficient when $R_{t+m}^{(n-m)} \cdot R_{t}^{(n)}$ is regressed on $s_{t}^{(n, m)}$. It implies that the regression of $s_{t}^{(n, m) *}$ on $s_{t}^{(n, m)}$ will give a coefficient of $1 / k$. The correlation of $E_{t} S_{t}^{(n, m) *}$ and $s_{t}^{(n, m)}$ will be one, but the ratio of their standard deviations will be $1 / k$. This model roughly fits the results from Tables 2, 3, and 4, except that the Table 2

11 We analyzed this question earlier in Campbell and Shiller [1984]. Using a different approach, we reached a similar conclusion for the period 1959-82. Over the period 1959-79, however, we found no evidence against equation (9) with an error term orthogonal to short rates. Indeed an IV regression of the type reported in the last column of Table 5 does give some positive coefficients over the shorter sample period. but the standard errors are quite large. 
regression coefficients tend to exceed the Table 4 standard deviation ratios for long horizons.

Equation (9) could be described as an overreaction model of the yield spread. It says that the long rate differs from the short rate in the direction implied by the expectations theory; however, the spread between the two rates is larger than can be justified by rational expectations of future short rate changes.

An alcernative way to describe equation (9) is to say that long rates underreact to short-term interest rates. This interpretation was offered in Campbell and Shiller [1984], although the empirical results in that paper were not as comprehensive as those here. We argued there that long rates are fairly well described as a distributed lag on short rates, where the distributed lag weights are all positive and their sum is very close to one. (It should be exactly one if predictable excess returns are stationary and the short-term interest rate follows a stochastic process with a unit root.) Relative to the predictions of the expectations theory, the estimated distributed lag gives too little weight to the current short rate, and too much weight to lagged short rates. In this sense the long rate underreacts to the current level of the short rate. 12

12 Mankiw and Summers [1984] described a similar underreaction model in which the long rate gives too much weight to expected future short rates, as opposed to lagged short rates. The underreaction story is not what one would expect given the evidence for "excess volatility" of long rates presented by one of the authors (Shiller [1979]). However that evidence depended on the assumption that the short-term interest rate is stationary, which is probably inappropriate for the postwar period in the U.S. See Shiller [1989] for further discussion. 
To see that the Campbell and Shiller [1984] model is consistent with our results here, consider its implications for the spread between the long rate and the short rate. The spread will be a distributed lag on past short rates with negative weight on the current short rate and positive weight on the distributed lag of past short rates, where all weights sum to zero. The Campbell and Shiller [1984] model implies that the spread's distributed lag representation would conform more closely to the expectations theory if the absolute value of all weights were scaled down towards zero. This also follows from equation (9). ${ }^{13}$

The deviation from the expectations theory described by equation ( 9 ) could be caused by time-varying risk premia which are correlated with expected increases in short-term interest rates. Alternatively, it is possible that in our sample period the bond market underestimated the persistence of movements in short rates (and thus overestimated the predictability of future short rate changes). Variations in the long. short spread were due primarily to sudden movements in short rates, and in this sample period long rates reacted too sluggishly to these sudden movements, so that the consequential movements in the spread were too large to be in accordance with the expectations theory.

13 Equation (9) is stronger in that it implies that the component of the spread which is orthogonal to current and lagged short rates should also be scaled down. 
Table la

$$
\begin{aligned}
& \text { Regression of } R_{t+m}^{(n-m)}-R_{t}^{(n)} \text { on Predicted Change } s_{t}^{(n, m)}
\end{aligned}
$$

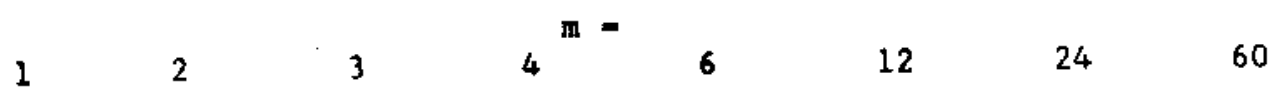

\begin{tabular}{|c|c|c|c|c|c|c|c|}
\hline 2 & $\begin{array}{c}0.002 \\
(0.238) \\
0.000 \\
0.000\end{array}$ & $\cdots$ & $\cdots$ & $\cdots$ & $\cdots$ & $--\cdot$ & $\cdots$ \\
\hline 3 & $\begin{array}{c}-0.176 \\
(0.362) \\
0.001 \\
0.001\end{array}$ & $\begin{array}{l}-0.361 \\
(0.502)\end{array}$ & -- & $\cdots$ & $\cdots$ & $\cdots$ & - - \\
\hline 4 & $\begin{array}{c}-0.437 \\
(0.469) \\
0.000 \\
0.002\end{array}$ & $\begin{array}{c}-0.611 \\
(0.562) \\
0.011 \\
0.005\end{array}$ & $\begin{array}{l}-0.452 \\
(0.366)\end{array}$ & $\cdots$ & $\cdots$ & $\cdots$ & - - \\
\hline 6 & $\begin{array}{c}-1.029 \\
(0.537) \\
0.000 \\
0.000\end{array}$ & $\begin{array}{c}-1.276 \\
(0.557) \\
0.000 \\
0.000\end{array}$ & $\begin{array}{c}-1.294 \\
(0.400) \\
0.001 \\
0.000\end{array}$ & $\begin{array}{l}-1.203 \\
(0.309)\end{array}$ & - . & - - & $\cdots$ \\
\hline 9 & $\begin{array}{c}-1.219 \mathrm{a} \\
(0.598) \\
0.019 \\
0.000\end{array}$ & $-\cdots$ & $\begin{array}{c}-1.682 \\
(0.486) \\
0.004 \\
0.000\end{array}$ & $\begin{array}{l}-1.482 \\
(0.311)\end{array}$ & $\begin{array}{l}-0.654 \\
(0.508)\end{array}$ & $-\cdots$ & $\cdots$ \\
\hline 12 & $\begin{array}{c}-1.3814 \\
(0.683) \\
0.038 \\
0.000\end{array}$ & $\begin{array}{c}-1.592 \mathrm{a} \\
(0.712) \\
0.064 \\
0.000\end{array}$ & $\begin{array}{c}-1.967 \\
(0.601) \\
0.003 \\
0.000\end{array}$ & $\cdots$ & $\begin{array}{c}-0.913 \\
(0.657) \\
0.056 \\
0.013\end{array}$ & $\cdots$ & -- \\
\hline 24 & $\begin{array}{c}-1.815 \mathrm{a} \\
(1.151) \\
0.122 \\
0.017\end{array}$ & $\begin{array}{c}-1.919 \mathrm{a} \\
(1.142) \\
0.099 \\
0.011\end{array}$ & $\begin{array}{c}-1.6944 \\
(0.939) \\
0.114 \\
0.007\end{array}$ & $\begin{array}{c}-1.482 a \\
(0.842) \\
0.150 \\
0.010\end{array}$ & $\begin{array}{c}-0.893 \mathrm{a} \\
(0.743) \\
0.134 \\
0.041\end{array}$ & $\begin{array}{c}-1.034 \\
(0.620) \\
0.047 \\
0.042\end{array}$ & $\cdots$ \\
\hline 36 & $\begin{array}{c}-2.239 a \\
(1.444) \\
0.122 \\
0.037\end{array}$ & $\begin{array}{c}-2.164 \mathrm{a} \\
(1.462) \\
0.104 \\
0.032\end{array}$ & $\begin{array}{c}-1.922 \mathrm{~s} \\
(1.210) \\
0.109 \\
0.022\end{array}$ & $\begin{array}{c}-1.692 \mathrm{a} \\
(1.065) \\
0.128 \\
0.035\end{array}$ & $\begin{array}{c}-1.1848 \\
(0.877) \\
0.128 \\
0.034\end{array}$ & $\begin{array}{c}-1.396 \\
(0.883) \\
0.034 \\
0.034\end{array}$ & $\begin{array}{l}-0.465 \\
(1.086)\end{array}$ \\
\hline
\end{tabular}


Table la (Continued)

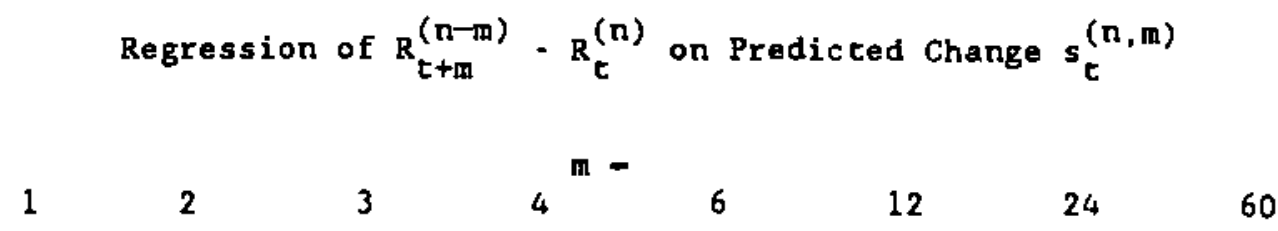

n-

$48 \quad \begin{array}{ccccccccc}4.665 \mathrm{a} & -2.561 \mathrm{a} & -2.208 \mathrm{a} & -1.960 \mathrm{a} & -1.447 \mathrm{a} & -1.736 & -0.725 & \ldots \\ & (1.634) & (1.662) & (1.392) & (1.206) & (0.991) & (1.027) & (1.233) & \\ & 0.087 & 0.055 & 0.091 & 0.093 & 0.129 & 0.019 & 0.115 & \\ & 0.023 & 0.046 & 0.028 & 0.032 & 0.033 & 0.033 & 0.353 & \\ & & & & & & & & \\ 60 & -3.099 \mathrm{a} & -2.941 \mathrm{a} & -2.525 \mathrm{a} & -2.276 \mathrm{a} & -1.750 \mathrm{a} & -2.022 & -0.811 & \ldots \\ & (1.749) & (1.795) & (1.523) & (1.318) & (1.096) & (1.205) & (1.369) & \\ & 0.079 & 0.070 & 0.080 & 0.088 & 0.099 & 0.024 & & \\ & 0.019 & 0.043 & 0.030 & 0.028 & 0.038 & 0.049 & & \\ & & & & & & & & \\ 120 & -5.024 \mathrm{a} & -4.695 \mathrm{a} & -4.298 \mathrm{a} & -3.944 \mathrm{a} & -3.198 \mathrm{a} & \ldots & \ldots & 4.575 \\ & (2.316) & (2.424) & (2.107) & (1.851) & (1.673) & & & (1.926) \\ & 0.029 & 0.032 & 0.028 & 0.047 & 0.060 & & & 0.146 \\ & 0.009 & 0.024 & 0.015 & 0.019 & 0.027 & & & 0.331\end{array}$

Notes: This table gives, in bold type, estimated regression slope coefficients of $R_{t+m}^{(n-m)}-R_{t}^{(n)}$ onto $s_{t}^{(n, m)}=(m /(n-m)) s_{t}^{(n, m)}$. According to the expectations theory, these coefficients should equal one. Constant terms (not shown) are included in all regressions. Hansen-Hodrick standard errors are below estimated coefficients, in bold type and parentheses. For each regression, the sample is the longest possible using data from 1952:1 through 1987:2, Where $\mathrm{n} / \mathrm{m}$ is an integer the table also gives, in ordinary type, two numbers from a Monte Carlo experiment. The first is the fraction of 1000 runs which produced an estimated regression coefficient which was further away from one in the same direction than the coefficient obtained in the data. The second number is the fraction of 1000 runs in which a 2-sided t test of the hypothesis that the coefficient equals one rejected the null more strongly than the $t$ test on the actual data. [a. Uses approximation that $R_{t+m}^{(n-m)}-R_{t+m}^{(n)} \cdot$ ] 
Table $1 b$

Regression of $R_{t+1}^{(n-1)}-R_{t}^{(n)}$ on Predicted Change $s_{t}^{(n, 1)}$ : Subsamples

Sample period (number of observations)

$1952-\quad 1952-\quad 1952-\quad 1960-\quad 1970-\quad 1979-$

$\begin{array}{llllll}1987 & 1978 & 1959 & 1969 & 1978 & 1987\end{array}$

$\begin{array}{lllll}(421) & (323) & (95) & (119) & (107) \quad(97)\end{array}$

$n=$

\begin{tabular}{|c|c|c|c|c|c|c|}
\hline 2 & $\begin{array}{c}0.002 \\
(0.238)\end{array}$ & $\begin{array}{l}-0.267 \\
(0.151)\end{array}$ & $\begin{array}{l}-0.271 \\
(0.193)\end{array}$ & $\begin{array}{l}-0.089 \\
(0.253)\end{array}$ & $\begin{array}{l}-0.436 \\
(0.419)\end{array}$ & $\begin{array}{c}0.347 \\
(0.342)\end{array}$ \\
\hline 3 & $\begin{array}{l}-0.176 \\
(0.362)\end{array}$ & $\begin{array}{l}-0.471 \\
(0.223)\end{array}$ & $\begin{array}{l}-0.194 \\
(0.284)\end{array}$ & $\begin{array}{l}-0.381 \\
(0.311)\end{array}$ & $\begin{array}{l}-0.855 \\
(0.691)\end{array}$ & $\begin{array}{c}0.167 \\
(0.577)\end{array}$ \\
\hline 4 & $\begin{array}{l}-0.437 \\
(0.469)\end{array}$ & $\begin{array}{l}-0.509 \\
(0.283)\end{array}$ & $\begin{array}{l}-0.101 \\
(0.388)\end{array}$ & $\begin{array}{l}-0.481 \\
(0.333)\end{array}$ & $\begin{array}{l}-0.850 \\
(0.893)\end{array}$ & $\begin{array}{l}-0.287 \\
(0.789)\end{array}$ \\
\hline 6 & $\begin{array}{l}-1.029 \\
(0.537)\end{array}$ & $\begin{array}{l}-0.537 \\
(0.340)\end{array}$ & $\begin{array}{l}-0.121 \\
(0.542)\end{array}$ & $\begin{array}{l}-0.567 \\
(0.393)\end{array}$ & $\begin{array}{l}-0.981 \\
(0.982)\end{array}$ & $\begin{array}{l}-1.345 \\
(0.902)\end{array}$ \\
\hline 9 & $\begin{array}{r}-1.219 a \\
(0.598)\end{array}$ & $\begin{array}{l}-0.394 a \\
(0.458)\end{array}$ & $\begin{array}{r}0.590 \mathrm{a} \\
(0.633)\end{array}$ & $\begin{array}{l}-0.598 \mathrm{a} \\
(0.544)\end{array}$ & $\begin{array}{l}-0.907 a \\
(1.124)\end{array}$ & $\begin{array}{r}-1.826 a \\
(1.066)\end{array}$ \\
\hline 12 & $\begin{array}{r}-1.381 a \\
(0.683)\end{array}$ & $\begin{array}{l}-0.6728 \\
(0.598)\end{array}$ & $\begin{array}{r}0.771 \mathrm{a} \\
(0.752)\end{array}$ & $\begin{array}{l}-1.044 a \\
(0.661)\end{array}$ & $\begin{array}{l}-1.216 a \\
(1.307)\end{array}$ & $\begin{array}{r}-1.778 \mathrm{a} \\
(1.237)\end{array}$ \\
\hline 24 & $\begin{array}{l}-1.815 \mathrm{a} \\
(1.151)\end{array}$ & $\begin{array}{c}-1.031 \mathrm{a} \\
(0.986)\end{array}$ & $\begin{array}{r}1.796 a \\
(1.557)\end{array}$ & $\begin{array}{l}-2.876 a \\
(1.284)\end{array}$ & $\begin{array}{r}-1.0638 \\
(1.594)\end{array}$ & $\begin{array}{l}-2.218 \\
(2.052)\end{array}$ \\
\hline 36 & $\begin{array}{r}-2.2398 \\
(1.444)\end{array}$ & $\begin{array}{r}-1.210 \mathrm{a} \\
(1.187)\end{array}$ & $\begin{array}{r}3.0218 \\
(2.379)\end{array}$ & $\begin{array}{l}-3.840 \mathrm{a} \\
(1.891)\end{array}$ & $\begin{array}{l}-1.245 a \\
(1.774)\end{array}$ & $\begin{array}{r}-2.791 \mathrm{a} \\
(2.431)\end{array}$ \\
\hline 48 & $\begin{array}{l}-2.665 \mathrm{a} \\
(1.634)\end{array}$ & $\begin{array}{r}-1.272 \mathrm{a} \\
(1.326)\end{array}$ & $\begin{array}{r}3.807 \mathrm{a} \\
(2.852)\end{array}$ & $\begin{array}{l}-4.373 a \\
(2.254)\end{array}$ & $\begin{array}{r}-1.293 a \\
(1.936)\end{array}$ & $\begin{array}{r}-3.468 \mathrm{a} \\
(2.714)\end{array}$ \\
\hline 60 & $\begin{array}{l}-3.0998 \\
(1.749)\end{array}$ & $\begin{array}{r}-1.4838 \\
(1.442)\end{array}$ & $\begin{array}{r}4.138 \mathrm{a} \\
(3.264)\end{array}$ & $\begin{array}{l}-4.886 a \\
(2.535)\end{array}$ & $\begin{array}{l}-1.424 a \\
(2.083)\end{array}$ & $\begin{array}{r}-4.052 a \\
(2.894)\end{array}$ \\
\hline 120 & $\begin{array}{r}-5.024 a \\
(2.316)\end{array}$ & $\begin{array}{l}-2.263 a \\
(1.869)\end{array}$ & $\begin{array}{r}3.099 a \\
(4.801)\end{array}$ & $\begin{array}{l}-6.029 a \\
(3.796)\end{array}$ & $\begin{array}{l}-2.103 \mathrm{a} \\
(2.650)\end{array}$ & $\begin{array}{r}-6.830 \mathrm{a} \\
(3.817)\end{array}$ \\
\hline
\end{tabular}

Noteg: This table gives the same regression coefficients and standard errors as Table 1a, except that $m=1$ throughout the table and results are reported for subsamples, No Monte Carlo results are reported. 
Table 2

Slope Coefficients in Regression of $s_{t}^{(n, m) *}$ on $s_{t}^{(n, m)}$

\begin{tabular}{|c|c|c|c|c|c|c|c|c|}
\hline$n=$ & 1 & 2 & 3 & $4^{\text {min }-}$ & 6 & 12 & 24 & 60 \\
\hline 2 & $\begin{array}{c}0.501 \\
(0.119) \\
0.000 \\
0.000\end{array}$ & -- & $\cdots$ & $\cdots$ & - - & - . & -- & $\cdots$ \\
\hline 3 & $\begin{array}{c}0.446 \\
(0.190) \\
0.000 \\
0.006\end{array}$ & -- & - - - & -- & $\cdots$ & - . & $\cdots$ & $\cdots$ \\
\hline 4 & $\begin{array}{c}0.436 \\
(0.238) \\
0.001 \\
0.022\end{array}$ & $\begin{array}{c}0.195 \\
(0.281) \\
0.011 \\
0.005\end{array}$ & $\cdots$ & $\cdots$ & $\cdots$ & --- & $\cdots$ & -. - \\
\hline 6 & $\begin{array}{c}0.237 \\
(0.167) \\
0.000 \\
0.000\end{array}$ & $\begin{array}{c}0.021 \\
(0.163) \\
0.010 \\
0.001\end{array}$ & $\begin{array}{c}-0.147 \\
(0.200) \\
0.001 \\
0.000\end{array}$ & - - - & $-\cdots$ & $-\cdots$ & - . & - - - \\
\hline 9 & $\begin{array}{c}0.151 \\
(0.165) \\
0.001 \\
0.000\end{array}$ & -- & $\begin{array}{c}-0.008 \\
(0.147) \\
0.015 \\
0.000\end{array}$ & ... & $\ldots$ & - - & $\cdots$ & - - - \\
\hline 12 & $\begin{array}{c}0.161 \\
(0.228) \\
0.006 \\
0.019\end{array}$ & $\begin{array}{c}0.078 \\
(0.192) \\
0.033 \\
0.004\end{array}$ & $\begin{array}{c}0.044 \\
(0.189) \\
0.023 \\
0.005\end{array}$ & $\begin{array}{c}-0.056 \\
(0.185) \\
0.022 \\
0.000\end{array}$ & $\begin{array}{c}0.044 \\
(0.329) \\
0.056 \\
0.013\end{array}$ & -- & $\cdots$ & - - \\
\hline 24 & $\begin{array}{c}0.302 \\
(0.212) \\
0.031 \\
0.067\end{array}$ & $\begin{array}{c}0.287 \\
(0.210) \\
0.096 \\
0.063\end{array}$ & $\begin{array}{c}0.269 \\
(0.230) \\
0.116 \\
0.086\end{array}$ & $\begin{array}{c}0.229 \\
(0.262) \\
0.117 \\
0.098\end{array}$ & $\begin{array}{c}0.186 \\
(0.324) \\
0.073 \\
0.100\end{array}$ & $\begin{array}{c}-0.017 \\
(0.372) \\
0.047 \\
0.042\end{array}$ & $\cdots$ & $\cdots$ \\
\hline 36 & $\begin{array}{c}0.614 \\
(0.230) \\
0.151 \\
0.318\end{array}$ & $\begin{array}{l}0.642 \\
(0.243) \star \\
0.211 \\
0.368\end{array}$ & $\begin{array}{c}0.610 \\
(0.101) \\
0.225 \\
0.070\end{array}$ & $\begin{array}{c}0.568 \\
(0.174) \\
0.210 \\
0.194\end{array}$ & $\begin{array}{c}0.526 \\
(0.225) \\
0.193 \\
0.223\end{array}$ & $\begin{array}{c}0.257 \\
(0.408) \\
0.119 \\
0.250\end{array}$ & $\cdots$ & \\
\hline
\end{tabular}


Table 2 (Continued)

Slope Coefficients in Regression of $s_{t}^{(n, m) *}$ on $s_{t}^{(n, m)}$

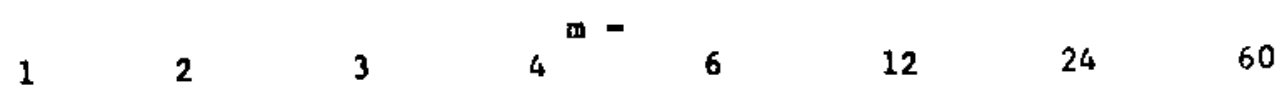

n -

48

$\begin{array}{ccccccc}0.873 & 0.929 & 0.931 & 0.939 & 0.942 & 0.720 & 0.137 \\ (0.291) & (0.271) & (0.240) & (0.203) & (0.088) & (0.333) & (0.617) \\ 0.256 & 0.289 & 0.299 & 0.321 & 0.299 & 0.230 & 0.115 \\ 0.817 & 0.868 & 0.898 & 0.913 & 0.697 & 0.613 & 0.353\end{array}$

60

$\begin{array}{cccccc}1.232 & 1.289 & 1.292 & 1.297 & 1.242 & 1.130 \\ (0.182) & (0.168) & (0.161) & (0.141) & (0.161) & (0.193) \\ 0.581 & 0.574 & 0.576 & 0.594 & 0.630 & 0.677 \\ 0.501 & 0.418 & 0.370 & 0.334 & 0.474 & 0.698\end{array}$

120

$\begin{array}{cccccccc}1.157 & 1.207 & 1.223 & 1.227 & 1.228 & 1.274 & 1.343 & 2.788 \\ (0.094) & (0.093) & (0.095) & (0.097) & (0.101) & (0.113) & (0.169) & (0.963) \\ 0.713 & 0.685 & 0.667 & 0.681 & 0.690 & 0.673 & 0.618 & 0.146 \\ 0.583 & 0.463 & 0.437 & 0.443 & 0.429 & 0.423 & 0.429 & 0.331\end{array}$

Notes: $s_{t}^{(n, m) \star}$, the perfect foresight spread, is defined in equation ( 3$)$ in the text. The elements given in bold type are the slope coefficients in a regression with a constant terw, and associated Hansen-Hodrick standard errors. By the expectations theory, the slope coefficlents should be one. The sample period for each element is the longest possible sample using data from 1952:1 to 1987:2. Since computation of $S_{t}^{(n, m) *}$ requires data extending $n-m$ periods into the future, the sample in the regression ends $n$-n months before $1987: 2$. The table also gives, in ordinary type, two numbers from a Monte Carlo experiment. These are constructed in the same way as the Monte Carlo results reportad in Table la. [*. Newey-West [1987] correction used because HansenHodrick procedure gave a negative standard error on constant or spread.J 
Table $3 a$

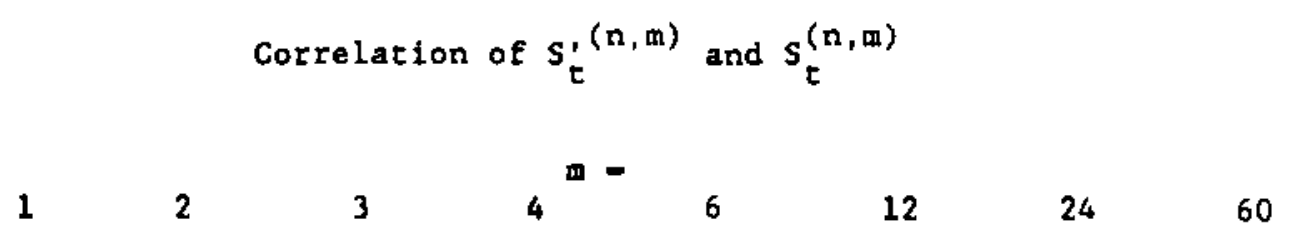

\begin{tabular}{|c|c|c|c|c|c|c|c|c|}
\hline 2 & $\begin{array}{c}0.736 \\
(0.148) \\
0.000 \\
0.094\end{array}$ & $\cdots$ & --- & $-\cdots$ & $\cdots$ & $\cdots$ & $=-$ & $\cdots$ \\
\hline 3 & $\begin{array}{c}0.761 \\
(0.190) \\
0.002 \\
0.437\end{array}$ & -- & -- & $\cdots$ & $\cdots$ & $\cdots$ & $\cdots$ & $\cdots$ \\
\hline 4 & $\begin{array}{c}0.720 \\
(0.213) \\
0.001 \\
0.285\end{array}$ & $\begin{array}{c}0.502 \\
(0.451) \\
0.063 \\
0.545\end{array}$ & $\cdots$ & $\cdots$ & $\cdots$ & -- & --- & $\cdots$ \\
\hline 6 & $\begin{array}{c}0.486 \\
(0.373) \\
0.003 \\
0.210\end{array}$ & $\begin{array}{c}0.058 \\
(0.566) \\
0.012 \\
0.118\end{array}$ & $\begin{array}{c}-0.355 \\
(0.556) \\
0.000 \\
0.015\end{array}$ & $\cdots$ & $\cdots$ & $\cdots$ & $\cdots$ & $\cdots$ \\
\hline 9 & $\begin{array}{c}0.374 \\
(0.421) \\
0.005 \\
0.181\end{array}$ & -- & $\begin{array}{c}-0.156 \\
(0.904) \\
0.008 \\
0.269\end{array}$ & --- & -- & $\cdots$ & $\cdots$ & $=-$ \\
\hline 12 & $\begin{array}{c}0.391 \\
(0.468) \\
0.007 \\
0.237\end{array}$ & $\begin{array}{c}0.282 \\
(0.909) \\
0.049 \\
0.603\end{array}$ & $\begin{array}{c}0.126 \\
(1.211) \\
0.017 \\
0.663\end{array}$ & $\begin{array}{c}-0.072 \\
(1.309) \\
0.017 \\
0.576\end{array}$ & $\begin{array}{c}-0.111 \\
(1.494) \\
0.015 \\
0.514\end{array}$ & $\cdots$ & $\cdots$ & $\cdots$ \\
\hline 24 & $\begin{array}{c}0.543 \\
(0.764) \\
0.021 \\
0.749\end{array}$ & $\begin{array}{c}0.629 \\
(0.941) \\
0.088 \\
0.920\end{array}$ & $\begin{array}{c}0.612 \\
(1.148) \\
0.102 \\
0.953\end{array}$ & $\begin{array}{c}0.512 \\
(1.565) \\
0.108 \\
0.964\end{array}$ & $\begin{array}{c}0.409 \\
(1.960) \\
0.062 \\
0.980\end{array}$ & $\begin{array}{c}0.212 \\
(1.865) \\
0.023 \\
0.930\end{array}$ & $=-$ & $\cdots$ \\
\hline 36 & $\begin{array}{c}0.770 \\
(0.531) \\
0.021 \\
0.749\end{array}$ & $\begin{array}{c}0.851 \\
(0.431) \\
0.088 \\
0.920\end{array}$ & $\begin{array}{c}0.860 \\
(0.442) \\
0.102 \\
0.953\end{array}$ & $\begin{array}{c}0.833 \\
(0.594) \\
0.108 \\
0.964\end{array}$ & $\begin{array}{c}0.776 \\
(0.917) \\
0.062 \\
0.980\end{array}$ & $\begin{array}{c}0.645 \\
(1.311) \\
0.023 \\
0.930\end{array}$ & $\cdots$ &.$\cdots$ \\
\hline
\end{tabular}


Table 3a (Continued)

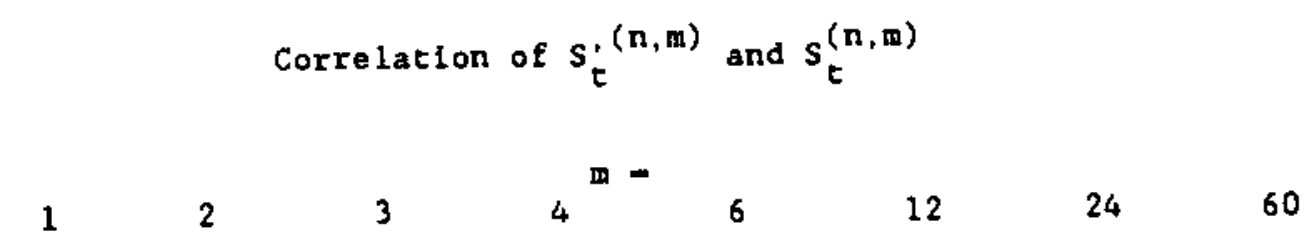

$\begin{array}{ccccccccc}n= & & & & & & & \\ 48 & 0.867 & 0.920 & 0.930 & 0.923 & 0.900 & 0.839 & 0.896 & \ldots \\ & (0.328) & (0.210) & (0.189) & (0.231) & (0.363) & (0.580) & (0.348) & \\ & 0.101 & 0.192 & 0.232 & 0.249 & 0.224 & 0.182 & 0.301 & \\ & 0.861 & 0.801 & 0.763 & 0.804 & 0.885 & 0.908 & 0.852 & \\ 60 & 0.912 & 0.948 & 0.956 & 0.954 & 0.939 & 0.893 & \ldots & \ldots \\ & (0.218) & (0.128) & (0.109) & (0.128) & (0.209) & (0.375) & & \\ & 0.115 & 0.213 & 0.271 & 0.270 & 0.232 & 0.206 & & \\ & 0.810 & 0.737 & 0.731 & 0.766 & 0.863 & 0.869 & & \\ & & & & & & & \\ 120 & 0.979 & 0.986 & 0.988 & 0.988 & 0.984 & 0.975 & 0.983 & 0.990 \\ & (0.045) & (0.027) & (0.021) & (0.023) & (0.038) & (0.062) & (0.041) & (0.020) \\ & 0.159 & 0.250 & 0.290 & 0.315 & 0.284 & 0.235 & 0.312 & 0.624 \\ & 0.667 & 0.642 & 0.568 & 0.593 & 0.698 & 0.680 & 0.708 & 0.623\end{array}$

Notes: This table gives, in bold type, correlation coefficients of $s_{t}^{(n, m)}$ with $s_{t}^{(n, m)}$ and estimated standard errors (In parentheses). $s_{t}^{(n, m)}$ is computed from equation (6) in the text based on a vector autoregression starting in 1952:1 and ending in 1987:2. The vector autoregression had four lags. The table also gives, in ordinary type, two numbers from a Monte Carlo experiment. The first number is the fraction of 1000 runs in which the difference between the estimated correlation and one was larger than in the actual data. The second number is the fraction of 1000 runs in which the difference between the estimated correlation and one, divided by its standard error, was larger than in the actual data. 
Table 3b

Correlation of $s_{t}^{(n, 1)}$ and $s_{t}^{(n, 1)}$ : Subsamples

Sample period (number of observations)

$\begin{array}{llllll}1952- & 1952- & 1952- & 1960- & 1970- & 1979- \\ 1987 & 1978 & 1959 & 1969 & 1978 & 1987 \\ (421) & (323) & (95) & (119) & (107) & (97)\end{array}$

n $=$

\begin{tabular}{|c|c|c|c|c|c|c|}
\hline 2 & $\begin{array}{c}0.738 \\
(0.148)\end{array}$ & $\begin{array}{c}0.626 \\
(0.115)\end{array}$ & $\begin{array}{c}0.668 \\
(0.134)\end{array}$ & $\begin{array}{c}0.785 \\
(0.170)\end{array}$ & $\begin{array}{c}0.303 \\
(0.169)\end{array}$ & $\begin{array}{c}0.696 \\
(0.138)\end{array}$ \\
\hline 3 & $\begin{array}{c}0.763 \\
(0.189)\end{array}$ & $\begin{array}{c}0.585 \\
(0.172)\end{array}$ & $\begin{array}{c}0.717 \\
(0.192)\end{array}$ & $\begin{array}{c}0.687 \\
(0.218)\end{array}$ & $\begin{array}{c}0.256 \\
(0.378)\end{array}$ & $\begin{array}{c}0.707 \\
(0.184)\end{array}$ \\
\hline 4 & $\begin{array}{c}0.723 \\
(0.212)\end{array}$ & $\begin{array}{c}0.604 \\
(0.204)\end{array}$ & $\begin{array}{c}0.729 \\
(0.254)\end{array}$ & $\begin{array}{c}0.589 \\
(0.283)\end{array}$ & $\begin{array}{c}0.538 \\
(0.406)\end{array}$ & $\begin{array}{c}0.675 \\
(0.228)\end{array}$ \\
\hline 6 & $\begin{array}{c}0.493 \\
(0.372)\end{array}$ & $\begin{array}{c}0.583 \\
(0.279)\end{array}$ & $\begin{array}{c}0.712 \\
(0.353)\end{array}$ & $\begin{array}{c}0.513 \\
(0.421)\end{array}$ & $\begin{array}{c}0.657 \\
(0.495)\end{array}$ & $\begin{array}{c}0.395 \\
(0.348)\end{array}$ \\
\hline 9 & $\begin{array}{c}0.386 \\
(0.419)\end{array}$ & $\begin{array}{c}0.561 \\
(0.394)\end{array}$ & $\begin{array}{c}0.742 \\
(0.382)\end{array}$ & $\begin{array}{c}0.417 \\
(0.646)\end{array}$ & $\begin{array}{c}0.628 \\
(0.638)\end{array}$ & $\begin{array}{c}0.282 \\
(0.383)\end{array}$ \\
\hline 12 & $\begin{array}{c}0.404 \\
(0.463)\end{array}$ & $\begin{array}{c}0.587 \\
(0.468)\end{array}$ & $\begin{array}{c}0.801 \\
(0.342)\end{array}$ & $\begin{array}{c}0.240 \\
(0.839)\end{array}$ & $\begin{array}{c}0.695 \\
(0.653)\end{array}$ & $\begin{array}{c}0.301 \\
(0.504)\end{array}$ \\
\hline 24 & $\begin{array}{c}0.558 \\
(0.743)\end{array}$ & $\begin{array}{c}0.829 \\
(0.349)\end{array}$ & $\begin{array}{c}0.963 \\
(0.088)\end{array}$ & $\begin{array}{l}-0.145 \\
(0.986)\end{array}$ & $\begin{array}{c}0.925 \\
(0.241)\end{array}$ & $\begin{array}{c}0.260 \\
(0.984)\end{array}$ \\
\hline 36 & $\begin{array}{c}0.779 \\
(0.509)\end{array}$ & $\begin{array}{c}0.922 \\
(0.180)\end{array}$ & $\begin{array}{c}0.987 \\
(0.021)\end{array}$ & $\begin{array}{l}-0.129 \\
(1.254)\end{array}$ & $\begin{array}{c}0.971 \\
(0.103)\end{array}$ & $\begin{array}{c}0.388 \\
(1.203)\end{array}$ \\
\hline 48 & $\begin{array}{c}0.872 \\
(0.313)\end{array}$ & $\begin{array}{c}0.968 \\
(0.079)\end{array}$ & $\begin{array}{c}0.991 \\
(0.009)\end{array}$ & $\begin{array}{l}-0.087 \\
(1.623)\end{array}$ & $\begin{array}{c}0.991 \\
(0.035)\end{array}$ & $\begin{array}{c}0.513 \\
(1.181)\end{array}$ \\
\hline 60 & $\begin{array}{c}0.914 \\
(0.210)\end{array}$ & $\begin{array}{c}0.986 \\
(0.037)\end{array}$ & $\begin{array}{c}0.993 \\
(0.007)\end{array}$ & $\begin{array}{c}0.116 \\
(2.087)\end{array}$ & $\begin{array}{c}0.997 \\
(0.011)\end{array}$ & $\begin{array}{c}0.626 \\
(1.006)\end{array}$ \\
\hline 120 & $\begin{array}{c}0.979 \\
(0.044)\end{array}$ & $\begin{array}{c}0.997 \\
(0.007)\end{array}$ & $\begin{array}{c}0.996 \\
(0.004)\end{array}$ & $\begin{array}{c}0.800 \\
(1.048)\end{array}$ & $\begin{array}{c}0.999 \\
(0.003)\end{array}$ & $\begin{array}{r}0.867 \\
(0.356)\end{array}$ \\
\hline
\end{tabular}

Notes: This table gives the same statistics as Table 3a, except that m = 1 throughout the table and results are reported for subsamples. No Monte Carlo results are reported. 


$$
\begin{aligned}
& \text { Table 4a } \\
& \sigma\left(\mathrm{S}_{t}^{(\mathrm{n}, \mathrm{m})}\right) / \sigma\left(\mathrm{S}_{\mathrm{t}}^{(\mathrm{n}, \mathrm{m})}\right)
\end{aligned}
$$

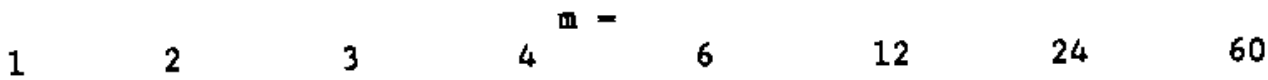

n

2

$$
\begin{gathered}
0.681 \\
(0.136) \\
0.000 \\
0.022
\end{gathered}
$$

3

$$
\begin{gathered}
0.586 \\
(0.145) \\
0.000 \\
0.008
\end{gathered}
$$

4

$$
\begin{array}{cc}
0.607 & 0.388 \\
(0.162) & (0.216) \\
0.000 & 0.000 \\
0.024 & 0.009
\end{array}
$$

6

$\begin{array}{ccc}0.501 & 0.357 & 0.404 \\ (0.145) & (0.196) & (0.225) \\ 0.000 & 0.000 & 0.001 \\ 0.004 & 0.002 & 0.024\end{array}$

9

$$
\begin{array}{ccc}
0.424 & \cdots & 0.317 \\
(0.129) & & (0.168) \\
0.000 & & 0.000 \\
0.000 & & 0.001
\end{array}
$$

$\begin{array}{ccccc}0.382 & 0.280 & 0.263 & 0.285 & 0.332 \\ (0.119) & (0.158) & (0.153) & (0.151) & (0.155) \\ 0.000 & 0.000 & 0.000 & 0.000 & 0.000 \\ 0.000 & 0.000 & 0.000 & 0.001 & 0.000\end{array}$

24

$\begin{array}{cccccc}0.303 & 0.255 & 0.236 & 0.224 & 0.238 & 0.272 \\ (0.135) & (0.249) & (0.283) & (0.262) & (0.217) & (0.135) \\ 0.000 & 0.000 & 0.000 & 0.000 & 0.000 & 0.000 \\ 0.000 & 0.017 & 0.020 & 0.013 & 0.004 & 0.000\end{array}$

$\begin{array}{cccccc}0.308 & 0.289 & 0.279 & 0.264 & 0.266 & 0.273 \\ (0.225) & (0.353) & (0.398) & (0.417) & (0.427) & (0.346) \\ 0.000 & 0.000 & 0.001 & 0.000 & 0.000 & 0.000 \\ 0.020 & 0.116 & 0.130 & 0.185 & 0.141 & 0.091\end{array}$




$$
\begin{aligned}
& \text { Table } 4 a \text { (Continued) } \\
& \sigma\left(s_{t}^{(n, m)}\right) / \sigma\left(s_{t}^{(n, m)}\right) \\
& \begin{array}{llllllll} 
& 2 & 3 & 4^{m-} & 6 & 12 & 24 & 60
\end{array}
\end{aligned}
$$

\begin{tabular}{|c|c|c|c|c|c|c|c|}
\hline $\begin{array}{c}0.334 \\
(0.274) \\
0.000 \\
0.070\end{array}$ & $\begin{array}{c}0.336 \\
(0.382) \\
0.001 \\
0.188\end{array}$ & $\begin{array}{c}0.335 \\
(0.422) \\
0.006 \\
0.212\end{array}$ & $\begin{array}{c}0.325 \\
(0.449) \\
0.004 \\
0.217\end{array}$ & $\begin{array}{c}0.323 \\
(0.481) \\
0.002 \\
0.239\end{array}$ & $\begin{array}{c}0.321 \\
(0.444) \\
0.001 \\
0.188\end{array}$ & $\begin{array}{c}0.376 \\
(0.526) \\
0.008 \\
0.286\end{array}$ & $\cdots$ \\
\hline $\begin{array}{c}0.357 \\
(0.291) \\
0.000 \\
0.093\end{array}$ & $\begin{array}{c}0.365 \\
(0.381) \\
0.017 \\
0.168\end{array}$ & $\begin{array}{c}0.367 \\
(0.415) \\
0.036 \\
0.219\end{array}$ & $\begin{array}{c}0.358 \\
(0.441) \\
0.018 \\
0.250\end{array}$ & $\begin{array}{c}0.353 \\
(0.476) \\
0.011 \\
0.261\end{array}$ & $\begin{array}{c}0.340 \\
(0.450) \\
0.003 \\
0.215\end{array}$ & $\cdots$ & - \\
\hline $\begin{array}{c}0.474 \\
(0.285) \\
0.043 \\
0.129\end{array}$ & $\begin{array}{c}0.481 \\
(0.337) \\
0.053 \\
0.205\end{array}$ & $\begin{array}{c}0.488 \\
(0.356) \\
0.070 \\
0.228\end{array}$ & $\begin{array}{c}0.487 \\
(0.372) \\
0.068 \\
0.236\end{array}$ & $\begin{array}{c}0.485 \\
(0.398) \\
0.079 \\
0.281\end{array}$ & $\begin{array}{c}0.478 \\
(0.383) \\
0.070 \\
0.232\end{array}$ & $\begin{array}{c}0.523 \\
(0.379) \\
0.081 \\
0.255\end{array}$ & $\begin{array}{c}0.552 \\
(0.385) \\
0.136 \\
0.275\end{array}$ \\
\hline
\end{tabular}

n $=$

Notes: Th1s table gives, in bold type, the standard deviation of $s_{t}^{(n, m)}$ divided by the standard deviation of $s_{t}^{(n, m)}$ and estimated standard errors of this ratio (in parentheses). $s_{t}^{(n, m)}$ is computed from equation (6) in the text based on a vector autoregression starting in $1952: 1$ and ending in 1987:2. The vector autoregression had four lags. The table also gives, in ordinary type, two numbers frow a Monte Carlo experiment. The first is the fraction of 1000 runs which produced an estimated standard deviation ratio which was further away from one in the same direction than the ratio obtained in the data. The second number is the fraction of 1000 runs in which a 2 -sided t test of the hypothesis that the ratio equals one rejected the null more strongly than the $t$ test on the actual data. 
Table $4 b$

$$
\sigma\left(S_{t}^{,(n, 1)}\right) / \sigma\left(S_{t}^{(n, 1)}\right): \text { Subsamples }
$$

Sample period (number of observations)

$\begin{array}{llllll}1952- & 1952- & 1952- & 1960- & 1970- & 1979- \\ 1987 & 1978 & 1959 & 1969 & 1978 & 1987 \\ & & & & & \\ (421) & (323) & (95) & (119) & (107) & (97)\end{array}$

\begin{tabular}{|c|c|c|c|c|c|c|}
\hline 2 & $\begin{array}{c}0.681 \\
(0.136)\end{array}$ & $\begin{array}{c}0.585 \\
(0.128)\end{array}$ & $\begin{array}{c}0.545 \\
(0.123)\end{array}$ & $\begin{array}{c}0.581 \\
(0.112)\end{array}$ & $\begin{array}{c}0.931 \\
(0.365)\end{array}$ & $\begin{array}{c}0.986 \\
(0.148)\end{array}$ \\
\hline 3 & $\begin{array}{c}0.586 \\
(0.144)\end{array}$ & $\begin{array}{c}0.503 \\
(0.132)\end{array}$ & $\begin{array}{c}0.483 \\
(0.117)\end{array}$ & $\begin{array}{c}0.582 \\
(0.112)\end{array}$ & $\begin{array}{c}0.674 \\
(0.389)\end{array}$ & $\begin{array}{c}0.922 \\
(0.144)\end{array}$ \\
\hline 4 & $\begin{array}{c}0.607 \\
(0.162)\end{array}$ & $\begin{array}{c}0.508 \\
(0.125)\end{array}$ & $\begin{array}{c}0.472 \\
(0.142)\end{array}$ & $\begin{array}{c}0.551 \\
(0.128)\end{array}$ & $\begin{array}{c}0.679 \\
(0.376)\end{array}$ & $\begin{array}{c}0.948 \\
(0.170)\end{array}$ \\
\hline 6 & $\begin{array}{c}0.500 \\
(0.144)\end{array}$ & $\begin{array}{c}0.461 \\
(0.099)\end{array}$ & $\begin{array}{c}0.489 \\
(0.180)\end{array}$ & $\begin{array}{c}0.429 \\
(0.102)\end{array}$ & $\begin{array}{c}0.599 \\
(0.277)\end{array}$ & $\begin{array}{c}0.824 \\
(0.200)\end{array}$ \\
\hline 9 & $\begin{array}{c}0.424 \\
(0.129)\end{array}$ & $\begin{array}{c}0.427 \\
(0.101)\end{array}$ & $\begin{array}{c}0.554 \\
(0.217)\end{array}$ & $\begin{array}{c}0.329 \\
(0.085)\end{array}$ & $\begin{array}{c}0.508 \\
(0.234)\end{array}$ & $\begin{array}{c}0.714 \\
(0.181)\end{array}$ \\
\hline 12 & $\begin{array}{c}0.382 \\
(0.119)\end{array}$ & $\begin{array}{c}0.400 \\
(0.100)\end{array}$ & $\begin{array}{c}0.649 \\
(0.275)\end{array}$ & $\begin{array}{c}0.309 \\
(0.103)\end{array}$ & $\begin{array}{c}0.441 \\
(0.235)\end{array}$ & $\begin{array}{c}0.627 \\
(0.165)\end{array}$ \\
\hline 24 & $\begin{array}{c}0.304 \\
(0.138)\end{array}$ & $\begin{array}{c}0.416 \\
(0.219)\end{array}$ & $\begin{array}{c}1.170 \\
(0.566)\end{array}$ & $\begin{array}{c}0.328 \\
(0.222)\end{array}$ & $\begin{array}{c}0.459 \\
(0.408)\end{array}$ & $\begin{array}{c}0.470 \\
(0.123)\end{array}$ \\
\hline 36 & $\begin{array}{c}0.311 \\
(0.227)\end{array}$ & $\begin{array}{c}0.473 \\
(0.272)\end{array}$ & $\begin{array}{c}1.510 \\
(0.575)\end{array}$ & $\begin{array}{c}0.316 \\
(0.238)\end{array}$ & $\begin{array}{c}0.504 \\
(0.411)\end{array}$ & $\begin{array}{c}0.392 \\
(0.142)\end{array}$ \\
\hline 48 & $\begin{array}{c}0.338 \\
(0.274)\end{array}$ & $\begin{array}{c}0.541 \\
(0.295)\end{array}$ & $\begin{array}{c}1.578 \\
(0.471)\end{array}$ & $\begin{array}{c}0.277 \\
(0.218)\end{array}$ & $\begin{array}{c}0.579 \\
(0.401)\end{array}$ & $\begin{array}{c}0.370 \\
(0.202)\end{array}$ \\
\hline 60 & $\begin{array}{c}0.360 \\
(0.290)\end{array}$ & $\begin{array}{c}0.589 \\
(0.293)\end{array}$ & $\begin{array}{c}1.539 \\
(0.406)\end{array}$ & $\begin{array}{c}0.235 \\
(0.115)\end{array}$ & $\begin{array}{c}0.637 \\
(0.378)\end{array}$ & $\begin{array}{c}0.365 \\
(0.260)\end{array}$ \\
\hline 120 & $\begin{array}{c}0.476 \\
(0.284)\end{array}$ & $\begin{array}{c}0.717 \\
(0.231)\end{array}$ & $\begin{array}{c}1.288 \\
(0.238)\end{array}$ & $\begin{array}{c}0.266 \\
(0.351)\end{array}$ & $\begin{array}{c}0.743 \\
(0.282)\end{array}$ & $\begin{array}{c}0.428 \\
(0.354)\end{array}$ \\
\hline
\end{tabular}

Netes: Th1s table gives the same statistics as Table 4a, except that in - 1 throughout the table and results are reported for subsamples. 
Table 5

Instrumental Variables Regression of $R_{t+1}^{(n-1)}-R_{t}^{(n)}$ on Predicted Change $s_{t}^{(n, 1)}$

Instruments

$$
\begin{aligned}
& \text { None } \\
& \text { (OLS) }
\end{aligned} s_{t-1}^{(n, 1)} s_{t-6}^{(n, 1)} s_{t-12}^{(n, 1)} x_{t, 12} \quad x_{t, 60}
$$

n

\begin{tabular}{|c|c|c|c|c|c|c|}
\hline 2 & $\begin{array}{c}0.002 \\
(0.238)\end{array}$ & $\begin{array}{l}-1.687 \\
(1.134)\end{array}$ & $\begin{array}{l}-1.997 \\
(1.484)\end{array}$ & $\begin{array}{l}-0.106 \\
(0.563)\end{array}$ & $\begin{array}{c}0.309 \\
(1.561)\end{array}$ & $\begin{array}{l}-4.578 \\
(4.921)\end{array}$ \\
\hline 3 & $\begin{array}{l}-0.176 \\
(0.362)\end{array}$ & $\begin{array}{l}-1.373 \\
(1.160)\end{array}$ & $\begin{array}{l}-3.491 \\
(2.166)\end{array}$ & $\begin{array}{l}-0.363 \\
(0.747)\end{array}$ & $\begin{array}{l}-0.164 \\
(1.374)\end{array}$ & $(-\cdots)$ \\
\hline 4 & $\begin{array}{l}-0.437 \\
(0.469)\end{array}$ & $\begin{array}{l}-1.223 \\
(1.046)\end{array}$ & $\begin{array}{l}-4.490 \\
(2.179)\end{array}$ & $\begin{array}{l}-0.733 \\
(1.017)\end{array}$ & $\begin{array}{l}-0.309 \\
(1.380)\end{array}$ & $\begin{array}{c}4.610 \\
(10.931)\end{array}$ \\
\hline 6 & $\begin{array}{l}-1.029 \\
(0.537)\end{array}$ & $\begin{array}{l}-1.678 \\
(0.953)\end{array}$ & $\begin{array}{l}-5.071 \\
(2.461)\end{array}$ & $\begin{array}{l}-1.664 \\
(1.574)\end{array}$ & $\begin{array}{l}-0.142 \\
(1.772)\end{array}$ & $\begin{array}{c}4.199 \\
(10.071)\end{array}$ \\
\hline 9 & $\begin{array}{r}-1.219 a \\
(0.598)\end{array}$ & $\begin{array}{r}-2.089 a \\
(1.027)\end{array}$ & $\begin{array}{r}-6.937 \mathrm{a} \\
(3.453)\end{array}$ & $\begin{array}{r}-2.395 a \\
(2.283)\end{array}$ & $\begin{array}{r}0.060 \mathrm{a} \\
(2.089)\end{array}$ & $\begin{array}{r}2.2008 \\
(5.364)\end{array}$ \\
\hline 12 & $\begin{array}{r}-1.381 \mathrm{a} \\
(0.683)\end{array}$ & $\begin{array}{r}-2.146 a \\
(0.959)\end{array}$ & $\begin{array}{l}-6.000 \mathrm{a} \\
(2.901)\end{array}$ & $\begin{array}{r}-2.997 \mathrm{a} \\
(3.144)\end{array}$ & $\begin{array}{r}-0.061 \mathrm{a} \\
(1.919)\end{array}$ & $\begin{array}{r}0.990 \mathrm{a} \\
(3.155)\end{array}$ \\
\hline 24 & $\begin{array}{r}-1.815 a \\
(1.151)\end{array}$ & $\begin{array}{l}-2.262 a \\
(1.127)\end{array}$ & $\begin{array}{l}-4.392 \mathrm{a} \\
(2.552)\end{array}$ & $\begin{array}{r}-4.219 \mathrm{a} \\
(3.692)\end{array}$ & $\begin{array}{c}-0.269 \mathrm{a} \\
(2.049)\end{array}$ & $\begin{array}{r}0.078 \mathrm{a} \\
(2.367)\end{array}$ \\
\hline 36 & $\begin{array}{l}-2.239 \mathrm{a} \\
(1.444)\end{array}$ & $\begin{array}{r}-2.328 \mathrm{a} \\
(1.398)\end{array}$ & $\begin{array}{l}-4.850 \mathrm{a} \\
(2.588)\end{array}$ & $\begin{array}{r}-4.586 a \\
(4.106)\end{array}$ & $\begin{array}{c}-0.611 \mathrm{a} \\
(2.153)\end{array}$ & $\begin{array}{l}-0.559 \mathrm{a} \\
(2.255)\end{array}$ \\
\hline 48 & $\begin{array}{r}-2.665 a \\
(1.634)\end{array}$ & $\begin{array}{l}-2.719 \mathrm{a} \\
(1.598)\end{array}$ & $\begin{array}{l}-5.767 a \\
(2.865)\end{array}$ & $\begin{array}{r}-4.477 \mathrm{a} \\
(4.251)\end{array}$ & $\begin{array}{l}-1.067 a \\
(2.376)\end{array}$ & $\begin{array}{r}-1.095 a \\
(2.313)\end{array}$ \\
\hline 60 & $\begin{array}{l}-3.099 \mathrm{a} \\
(1.749)\end{array}$ & $\begin{array}{r}-3.058 \mathrm{a} \\
(1.728)\end{array}$ & $\begin{array}{r}-6.205 a \\
(3.039)\end{array}$ & $\begin{array}{r}-4.5131 \\
(4.433)\end{array}$ & $\begin{array}{l}-1.518 \alpha \\
(2.539)\end{array}$ & $\begin{array}{r}-1.632 \mathrm{a} \\
(2.384)\end{array}$ \\
\hline & $\begin{array}{l}-5.024 \mathrm{a} \\
(2.316)\end{array}$ & $\begin{array}{l}-4.908 \mathrm{a} \\
(2.405)\end{array}$ & $\begin{array}{l}-8.063 \mathrm{a} \\
(3.968)\end{array}$ & $\begin{array}{r}-4.909 a \\
(6.256)\end{array}$ & $\begin{array}{l}-3.524 a \\
(3.394)\end{array}$ & $\begin{array}{l}-3.839 a \\
(2.992)\end{array}$ \\
\hline
\end{tabular}

Notes on next page. 
Table 5 gives, in bold type, estimated regression slope coefficlents of $R_{t+I}^{(n-I)} \cdot R_{t}^{(n)}$ onto $s_{t}^{(n, m)}=(m /(n-m)) s_{t}^{(n, m)}$. Regressions were estimated using instrumental varfables, which are identified at the top of each column. The first three columns use lagged spreads, the last two use the difference between the current short rate and a 12 -month backwards moving average $\left(x_{t, 12}\right)$ and the difference between the current short rate and $a$ 60 -month backwards moving average $\left(x_{t, 60}\right)$. According to the model given in equation ( 8 ), the slope coefficients should equal one. Constant terms (not shown) are included in all regressions. Hansen-Hodrick standard errors are below estfmated coefficients, in parentheses. For each regression, the sample is the longest possible using data from 1952:1 through 1987:2. [a. Uses approximation that $R_{t+m}^{(n-m)}=R_{t+m}^{(n)} \cdot$ ] 


\section{References}

Campbel1, John Y., "A Defense of Traditional Hypotheses about the Term Structure of Interest Rates", Journal of Finance 41:183-93, March 1986.

Campbell, John $Y$, , and Robert $\rfloor$. Shiller, "A Simple Account of the Behavior of Long-Term Interest Rates", American Economic Review Papers and Proceedings 74:44-8, May 1984 .

Campbell, John Y., and Robert J. Shiller, "Cointegration and Tests of Present Value Models", Journal of Political Economy 95:1062-1088, October 1987.

Cox, John C., Jonathan E. Ingersol1, and Stephen A. Ross, "A Reexamination of Traditional Hypotheses about the Term structure of Interest Rates", Journal of Finance $36: 769-99,1981$.

Fama, Eugene F., "The Information in the Term structure", Journal of Financtal Economics 13:509-28, 1984.

Fama, Eugene F., "Term structure Forecasts of Interest Rates, Inflation, and Real Returns", Center for Research in Securlty Prices Working Paper No. 233, University of Chicago, January 1988.

Fama, Eugene F., and Robert R. Bliss, "The Information in LongMaturity Forward Rates", American Economic Reviaw 77:680-692, September 1987.

Froot, Kenneth A., "New Hope for the Expectations Hypothesis of the Term Structure of Interest Rates", Journal of Finance 44:283-305, June 1989.

Hansen, Lars Peter, and Robert J. Hodrick, "Forward Rates as Optimal Predictors of Future Spot Rates", Journal of Political Econony 88:829$853,1980$.

Mank1w, H. Gregory and Matthew D. Shapiro, "Do We Refect Too often? Small Sample Properties of Tests of Rational Expectations Models". Economics letters 20:139-145, 1986 .

MankIw, N, Gregory and Lawrence H. Summers, "Do Long-Term Interest Rates Overreact to Short-Tern Interest Rates?" Brookings Paperson Bconomic Activicy $1: 223-242,1984$.

MLshkin, Frederlc S. [1988a], "The Information in the Term structure: Some Furcher Results", Journal of Applled Fconometrics 3:307-314, 1988.

MIshkin, Frederlc s, [1988b], "What Does the Term Structure Te1l Us About Future Inflation?" National Bureau of Econoric Research Working Paper No. 2626, June 1988. 
Mishkin, Frederic S. [1988c], "The Information in the Longer-Maturity Term Structure About Future Inflation", unpublished paper, Columbia University, 1988 .

McCulloch, J. Huston, "U. S. Goverment Term Structure Data", unpublished paper, 1987.

Newey, Whitney K. and Kenneth D. West, "A Simple, Positive Definite, Heteroscedasticity and Autocorrelation Consistent Covariance Matrix", Econometrica 55:703-708, 1987.

Shiller, Robert J., "The Volatility of Long-Term Interest Rates and Expectations Theories of the Term Structure," Journal of Pollfical Economy 87:1190-19, December 1979 .

Shiller, Robert J. (1989a), Market Volatility, MIT Press, forthcoming 1989.

Shiller, Robert J. [1989b], "The Term Structure of Interest Rates," in Benjamin Friedman and Frank Hahn, editors, The Handbook of Monetary Economics. North Holland, forthcoming 1989.

Shiller, Robert J., John Y. Campbell, and Kermit L. Schoenholtz, "Forward Rates and Future Policy: Intexpreting the Term Structure of Interest Rates", Brookines Papers on Economic Activity 1:173-217, 1983.

Stambaugh, Robert F., "Bias in Regressions with Lagged Stochastic Regressors", unpublished paper, Graduate School of Business, University of Chicago, 1986.

Stock, James $\mathrm{H}$, and Matthew Richardson, "Drawing Inferences from Statistics Based on Multi-Year Asset Returns", unpublished paper, Harvard University and Stanford University, June 1989. 1984 .

White, Halbert, Asymptorfc Theory for Econometriclans, Academic Press, 